\title{
ANCIENT DEPLETED SUBCONTINENTAL LITHOSPHERE UNDER SIBERIAN \\ PLATFORM: Nd-Sr ISOTOPIC AND REE EVIDENCE FROM GARNET PERIDOTITE XENOLITHS OF MIR PIPE (WESTERN YAKUTIA).
}

\section{A.Z. Zhuravlev; E.E. Laz'ko and A.I. Ponomarenko.}

Insti.of the Ore Deposits Geology, Petrography, Mineralogy \& Geochemistry, USSR Academy of Sci., Moscow, USSR.

A combined petrological and geochemical study of two garnet peridotite xenoliths (A-246 and A-339) from Mir kimberlite pipe has been accomplished. Both fragments are typical partly serpentinized appreciably depleted lherzolites (containing $\mathrm{Al}_{2} \mathrm{O}_{3}$ 1.79 and $2.86 ; \mathrm{CaO} 2.50$ and 3.37 wt.\% respectively). The textures of the rocks are protogranular with some manifestations of deformation. Equilibrium P-T conditions of peridotites suggest they are fragments of thermally unperturbed "normal" (cold) palaeolithosphere.

Besides microprobe and bulk chemical analyses the concentrations of ten REE in coexisting minerals of peridotites have been measured by isotope dilution technique, and the isotope composition of $\mathrm{Sr}$ and $\mathrm{Nd}$ has been determinated. The distributions of REE in minerals are similar to other garnet peridotites from kimberlites (Shimizu, 1975): the main phases concentrating lanthanoids are garnet and clinopyroxene which strongly LREE depleted (low Ce/Yb) and LREE enriched (high $\mathrm{Ce} / \mathrm{Yb}$ ) respectively. Olivine and orthopyroxene contain the extremely low concentrations of REE in comparison with the concentrators of the latter and render to be appreciably contaminated with a small portions of a kimberlite matter in spite of careful cleaning procedure of analysed minerals separates.

The garnet-clinopyroxene pair for A-339 peridotite define the mineral Sm-Nd age of $1.7 \pm 0.1$ b.y (Fig. 1). The calculated model Sm-Nd age $\mathrm{T}_{\text {CHUR }}$ of this rock is much older $-3.0 \mathrm{~b} . \mathrm{y}$. This value is in appreciable disagreement with the $2.1 \mathrm{~b} . \mathrm{y}$. model Rb$\mathrm{Sr}$ age defined by clinopyroxene $\mathrm{Rb}-\mathrm{Sr}$ systematics. In any case however the age of A-339 peridotite is significantly older than the intrusion age of the host kimberlite from Mir pipe ( $360 \mathrm{Ma})$. The calculated $\epsilon^{\mathrm{T}} \mathrm{Nd}$ value for a parental rock A-339 is exceedingly high $(+23.0 \pm 1.6)$ and indicative of a long-term extreme REE depletion of an upper mantle region from which the examined xenolith have been excavated by a kimberlite melt.

The Sm-Nd age of A-246 peridotite (also defined by garnetclinopyroxene pair) is $0.91 \pm 0.01$ b.y (Fig. 1). Therefore this rock is almost twice younger than the other one, but it is still significantly older in comparison with the including kimberlite. However the calculated $\epsilon^{\mathrm{T}} \mathrm{Nd}$ value for a parental A-246 rock is $+22.5 \pm 0.5$, i.e. actually equal to the other fragment.

The unexpected and impressive result of $\mathrm{Sm-Nd}$ dating is the old isotopic ages of both xenoliths studied. Nevertheless these ages are minimum value. Such conclusion can be easily drawn when considering the factors which could distort the data obtained (contamination of analyzed mineral separates by small portions of kimberlite, isotopic exchange between coexisting garnet and 


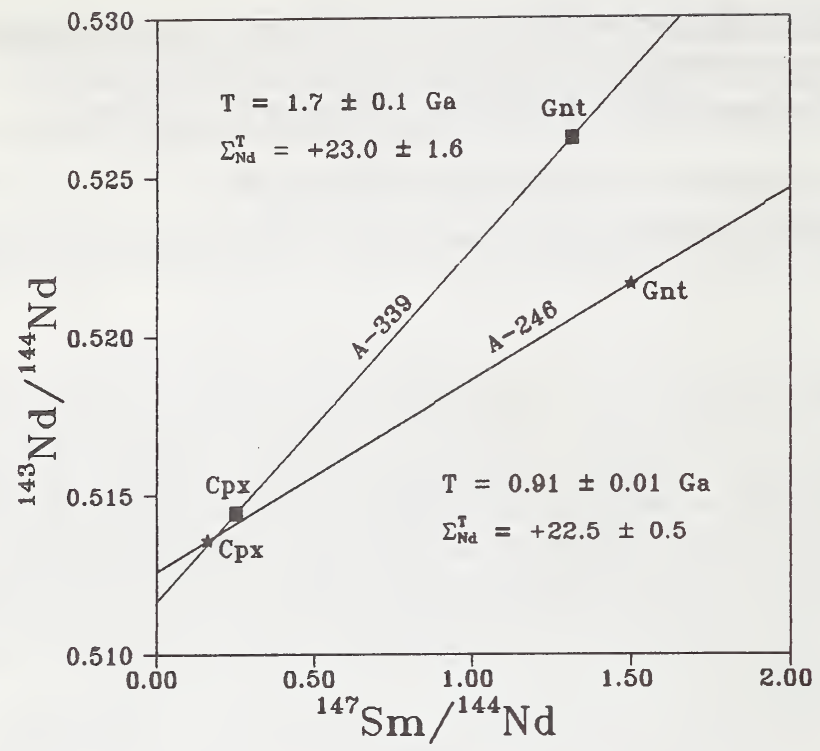

Figure. Sm-Nd age diagram for

coexisting garnet and clinopyroxene

from A-339 and A-246 peridotites.

clinopyroxene in mantle, etc.). Therefore peridotite examined do actually have much older age than kimberlite from Mir pipe.

The large time interval between the age of mantle samples and including volcanic rocks is rather unusual. We are aware of the only such example among mantle peridotites - sample M-602 also originating from Mir pipe (McCulloch, 1986). Our new data unequivocally confirm a possibility of ancient isotopic marks conservation in ultramafic rock xenoliths from kimberlites. Petrologic implications of these old $\mathrm{Sm}-\mathrm{Nd}$ ages are that they correspond either to the time of crystallization of parental rocks of xenoliths or to the moment of their final reequilibration which has been accompained by perfect isotope homogenization. In other words, after the stabilization of garnets' and clinopyroxenes' isotopic systems $(1.7$ and $0.91 \mathrm{~b} . \mathrm{y}$. for nodules A-339 and A-246 respectively) the rocks examined did not survive a significant thermal event including their transport in a kimberlite melt.

The other striking feature of rocks studied is their abnomarlly high $\epsilon^{\mathrm{T}} \mathrm{Nd}$ values. The latter strongly exceed $\epsilon_{\mathrm{Nd}}$ values usually detected in majority of mantle volcanics and their xenoliths. Assuming that both rocks have developed as practically closed systems (on a xenolith-size scale), their highly positive $\epsilon^{\mathrm{T}} \mathrm{Nd}$ marks require long-lived strongly REE depleted source. Since in a convective mantle (i.e. contemporary asthenosphere) such values are much less, the only realistic source of discussed xenoliths could be seen in a subcontinental lithosphere under Siberian craton. Similar anomalously REE depleted mantle rocks have been detected in some other 
localities in Central and East Asia - Transbaikal Lake region, Mongolia, and Eastern China. We suggest that a definite layer of the lithospheric mantle under the eastern part of Asia continent may have an anomalous $\mathrm{Nd}$ isotope composition. This layer may correspond to a presumed highly depleted mantle reservoir (Zindler, Hart, 1986).

The difference between Sm-Nd and Rb-Sr model age of both peridotites does not allow to develop a simple one-stage model explaining the evolution of their parental sources. The history of development of the corresponding mantle region under Siberian craton has been long and complex. There is hardly possible to reconstruct it unequivocally using the data obtained. It is quite evidently however that the mantle evolution of both rocks have included a protolith depletion and enrichment by some main oxides and incompatible elements, recrystallization processes, cooling and other events. Two most realistic alternative petrogenetic models are considered. The early partial melting episode is most important event in both of them. Probably it documents the initial development and stabilization of the subcontinental lithosphere. Later incompatible element enrichment event postulated by the first scenario, documents reactivation episode which have occured in stable lithospere. Such process is problematic in the second model. Sm-Nd ages of peridotites mark the time of their final isotopic "closing".

\section{REFERENCES}

MCCULLOCH M.T. 1986. Sm-Nd systematics in eclogite and garnet peridotite nodules from kimberlites: implications for the early differentiation of the Earth. Geol. Soc. Austral., Abstr.,no.16, p.p. 285-287.

SHIMIZU N. 1975. Rare earth elements in garnets and clinopyroxenes from garnet lherzolite nodules in kimberlites. Earth and Planetaty Science Letters, v. 25, no.1, p.p. 26-32.

ZINDLER A. and HART S.R. 1986. Chemical Geodynamics. Annual Reviews of Earth and Planetary Sciences, v 14, p.p. 493571 . 